later, mixed infections are more likely. Thus eradication of a single pathogen, such as the gonococcus, may not necessarily be accompanied by resolution of pelvic inflammatory disease.

Finally, it seems unlikely that pelvic inflammatory disease is caused by the same mechanism throughout the world. In each country doctors should have a clear idea of the prevalent infecting organisms, and it is a pity that so few data are available in Britain. A major survey is long overdue.

1 Weström, L, and Mårdh, P-A, in Non-gonococcal Urethritis and Related Infections, ed $\mathrm{D}$ Hobson and $\mathrm{K} \mathrm{K}$ Holmess, $\mathrm{p}$ 84. Washington, DC, American Society for Microbiology, 1977.

2 Goldstein, L Z, Obstetrics and Gynecology, 1955, 6, 193.

3 Thompson, S E, and Hager, W D, Sexually Transmitted Diseases, 1977, 4, 105.

4 Cunningham, F G, et al, Obstetrics and Gynecology, 1978, 52, 161.

5 Mårdh, P-A, et al, in Non-gonococcal Urethritis and Related Infections, ed D Hobson and K K Holmess, p 77. Washington DC, American Society for Microbiology, 1977.

6 Schachter, J, et al, fournal of the American Medical Association, 1975, 231, 1252.

7 Mardh, P-A, et al, New England Fournal of Medicine, 1977, 296, 1377.

${ }^{8}$ Eschenbach, D A, et al, New England Fournal of Medicine, 1975, 293, 166

${ }^{9}$ Mårdh, P-A, and Weström, L, British Fournal of Venereal Diseases, 1970, 46, 179.

10 Sweet, R L, American fournal of Obstetrics and Gynecology, 1975, 122, 891.

11 W'eström, L, and Mårdh, P-A, in Genital Infections and Their Complication, ed D Danielsson, L Juhlin, and P-A Mårdh, p 157. Stockholm, Almqvist and Wiksell, 1975.

12 Gorbach, S L, et al, American fournal of Obstetrics and Gynecology, 1973, 117, 1053.

${ }^{13}$ Chow, A W, et al, American fournal of Obstetrics and Gynecology, 1975, 122, 876 .

\section{ARM at Liverpool}

Last year's Annual Representative Meeting was relatively subdued. But this year the 492 -motion agenda ${ }^{1}$ is likely to prompt some lively debates, while the meeting will be overshadowed by the disappointing pay review. ${ }^{2}$ By the time the BMA's policy-making body opens its first session in Liverpool University at $2 \mathrm{pm}$ on Monday 25 June the Council should have appointed a new Secretary to succeed Dr Elston GreyTurner at the end of this year. The decision will remove the urgency from one priority motion, a call by Trent North Regional Hospital Junior Staff Committee that the Secretary should in future be elected by the membership for seven years, with eligibility for re-election. Though this is a practice in some unions, representatives might consider deferring debate on this suggestion until the membership at large has had a chance to think carefully on a change that could profoundly alter the character of the secretaryship.

The ARM took a bold decision last year to invest in strengthening the BMA's peripheral structure. ${ }^{3}$ This year the bill comes up for payment in the form of a Council recommendation to increase the subscription from $£ 50$ to $£ 70$ at the full rate. While in the short term the rise in subscriptionwhich with standard rate tax relief is only around $30 \mathrm{p}$ a week for the full subscription-is the quickest way of improving the BMA's finances, in the longer term the soundest answer is a substantial increase in membership. Home membership has been improving slowly, but if the BMA could emulate the RCN's dramatic membership rise of 90000 to 142000 in two years the Association would be immensely reinforced politically and the Treasurer would have fewer worries about finding more money to strengthen the BMA where it matters-on the ground. One reason that has almost certainly contributed to the RCN's success is its introduction of DOCAS (deduction of contributions at source). As Professor Roger Dyson points out in an article at p 1658, the system whereby the employer deducts subscriptions along with tax, superannuation, etc, has advantages and two of the most telling are that it seems to make recruitment and retention of members easier. Some hospital doctors and the vast majority of GPs already use such a system successfully to contribute to their respective trust funds. But the time has come for the BMA to consider the adoption of DOCAS, and the six grouped motions on the agenda will give the ARM an opportunity to decide whether and how to introduce it.

Although the full draft of the ethical handbook has not been published-and the division which suggests that this should be done in the $B M F$ may not realise that it would cost several thousand pounds-its discussion in the medical press has prompted an array of motions which could make Dr M J G Thomas one of the busiest committee chairmen at the ARM. It is encouraging that divisions have shown such interest in the draft. In a society where an individual's interests can so often clash with the community's interests and state regulations doctors look for some firm guidance, and the BMA, as the only professional organisation representing all types of doctor, is in a unique position to prepare such advice.

The agenda committee has selected 15 motions for priority debate. Among the diverse proposals are calls to reject RAWP, to introduce vouchers for private treatment, to cut back medical student admissions, to improve career opportunities for domestically committed doctors, to toughen anti-smoking measures, to combat alcoholism more vigorously, and to strengthen further the BMA's peripheral structure. One late arrival to the agenda will be the Wilson working party report on manpower. After last year's censure of Council for inaction on manpower this report will surely stir conflicting passions among representatives. Indeed, the meeting might well judge it wise to allow the profession at large to discuss the report before deciding on all the proposals, though the setting up of the national and BMA manpower committees is one positive step that is urgently needed.

But the first priority motion to be debated is on the Review Body. Bromley wants the meeting to deplore "the repeated manipulation of the date of release of Review Body reports." After this year's hold up the motion will undoubtedly get wide support, but the real interest will be in the contents of the Ninth Report and on the future of the Review Body. All the profession's craft conferences will have met before the ARM, although COMAR (p 1642) did so before the report came out and the Senior Hospital Staff Conference was held the day after it appeared. Even so, the ARM will be told of the crafts' reactions to the report, and though the Review Body's recommendations are not referred to in the formal agenda no doubt Dr Brian Lewis, chairman of the RB, will ensure that they are debated.

So far the GPs and juniors have agreed to start discussions on implementing the report, but the CCHMS, which meets on 14 June (after the $B M F$ went to press), is unlikely to follow suit. The consultants' leaders have always made it clear that the new contract was intended to be work sensitive and to improve remuneration substantially and the award will not consummate these aims. Understandably, the Senior Hospital Staffs Conference (p 1640) was angered, firstly particularly as the Health Departments had told the Review Body it was not their intention to provide additional funds for emergency recall fees and also by their assumption that "where the source of finance had not been identified, the professions were content for the cost of each [separately identified] item to be 
found within the overall cost of the new contract."2 Addressing the conference, Mr D E Bolt, the consultants' chief negotiator, has put the record straight on this naive and damaging Whitehall evidence, about which the Representative Body will also have some angry comments to make. Certainly, by pricing 13 NHDs as the standard week instead of 10 as the profession wanted the Review Body has made the contract unattractive to consultants. This serious devaluation of the NHD has been aggravated by two other decisions. Three of those 13 NHDs would have no long-term security of tenure, and the emergency recall fees have been priced with money obtained by reducing the basic salary - a change that has also been recommended for the existing contract. So, despite a highly critical leading article in the Guardian calling the award to consultants excessive, the new contract is in jeopardy. GPs have also been angered by being told that, because their indirect expenses have been overpaid for the last three years, this year the increase awarded is only $£ 200$-a sum that will barely cover some doctors' higher petrol costs-thus reducing their net remuneration increase to around $18 \%$ on average. So it is highly probable that the $\mathrm{RB}$ will react unfavourably to a report that doctors had looked forward to as repairing some of the damage inflicted on doctors' incomes since 1975.

This Ninth Report will not be an auspicious start to the profession's relations with the new Government. Nor will it make life easy for the profession's leaders, though no one could have worked harder than they for doctors. But politics is a harsh business, and a major task at Liverpool will be to persuade the profession's representatives to keep their cool in deciding how best to overcome this setback.

1 British Medical fournal, 1979, 1, 1502.

2 Review Body on Doctors and Dentists' Remuneration, Ninth Report, Cmnd 7574. London, HMSO, 1979.

3 British Medical fournal, 1978, 2, 301.

4 Guardian, 7 June 1979, 12.

\section{Treatment of angioedema}

Hereditary angioedema is characterised by recurrent attacks of localised oedema affecting skin and mucosal surfaces. Oedema of the skin, though distressing, is not usually dangerous; but oedema affecting the gastrointestinal mucosa may present as intestinal obstruction, while oedema of the mucosa of the upper respiratory tract (the "oedema glottidis" mentioned by Osler ${ }^{1}$ in his description of the condition) may threaten life. Hereditary angioedema is an uncommon disease, inherited as an autosomal dominant. A form of angioedema with similar clinical features has been found in cases of lymphosarcoma, ${ }^{2}$ chronic lymphatic leukaemia, ${ }^{3}$ and rectal carcinoma. ${ }^{4}$

The primary biochemical fault in both hereditary and acquired angioedema associated with cancer is deficiency or abnormality of an inhibitor in the complement pathway. ${ }^{2} 56$ Like the coagulation system, the complement pathway consists of a "cascade," precursor proteins being converted by specific proteolytic reactions to a series of active enzymes. Thus $\mathrm{Cl}$ is converted to $\mathrm{Cl}$ esterase, and this acts on $\mathrm{C} 4$ and $\mathrm{C} 2$ to activate the rest of the classical complement pathway (which consists of the nine proteins $\mathrm{Cl}-\mathrm{C9}$ ). This pathway is the major effector mechanism of the antibody response, and its activation leads to the destruction of foreign cells and to acute inflammation. Regulation of the system depends in part on inhibitors in the serum. The inhibitor of $\mathrm{Cl}$ esterase (C1 INH), for example, prevents conversion of $\mathrm{Cl}$ to $\mathrm{Cl}$ esterase by binding with $\mathrm{Cl}$. This is the inhibitor affected in angioedema. In hereditary angioedema $80 \%$ of patients have only $5-30 \%$ of the normal concentration of $\mathrm{Cl}$ INH; the rest have a normal concentration of a non-functioning protein antigenically identical to $\mathrm{Cl} \mathrm{INH}$. In acquired angioedema the complement profile includes a low $\mathrm{Cl}$ concentration as well as low $\mathrm{Cl} \mathrm{INH}, \mathrm{C} 2$, and $\mathrm{C} 4$ concentrations.

Clinical attacks of angioedema, which are usually selflimiting, are attributed to activation of $\mathrm{Cl}$, consumption of $\mathrm{C} 2$ and $\mathrm{C} 4$, and release of a vasoactive peptide, possibly from C2. Some attacks are spontaneous while others follow trauma, which triggers the fibrinolytic pathway and releases plasmin to activate $\mathrm{Cl}$ esterase. ${ }^{78}$ Treatment with plasmin inhibitors such as epsilon-aminocaproic acid $^{9}$ and tranexamic acid ${ }^{10}$ reduces the number of attacks but does not entirely prevent them. An alternative approach is to give androgens, which correct the low concentrations of $\mathrm{Cl} \mathrm{INH}$, probably by inducing its synthesis. This provides effective prophylaxis ${ }^{11}{ }^{12}$; but the use of androgens, particularly methyltestosterone, is limited by the dangers of masculinisation and damage to the liver. Danazol, an androgen derivative with minimal virilising properties, is, however, highly efficacious in preventing attacks $^{13}$ : the drug raises the concentration of $\mathrm{Cl}$ INH and restores that of $\mathrm{C} 4$ to the normal range.

Recently, Cohen et al have reported the successful use of danazol in a patient who had acquired angioedema associated with a rectal carcinoma. ${ }^{4} \mathrm{He}$ had had two episodes of laryngeal oedema requiring intubation, and an abnormal complement profile, before the rectal adenocarcinoma was found. After resection of the tumour laryngeal oedema recurred. When treatment with danazol was started the complement concentrations returned to normal and the patient remained free of attacks even though the $\mathrm{Cl}$ INH subsequently fell to pretreatment concentrations. This anomaly suggests that danazol may interfere with activation of $\mathrm{Cl}$ as well as increasing C1 INH production initially.

Danazol, then, is proving to be an effective treatment for a potentially fatal condition. We still need, however, to answer questions about the "switching on" and "switching off" of the complement pathway. The answers may suggest methods to overcome the unsolved problem of treating or reversing attacks of angioedema once they have begun.

1 Osler, W, American fournal of Medical Science, 1888, 95, 362.

2 Caldwell, J R, et al, Clinical Immunology and Immunopathology, 1972, 1, 39.

3 Day, N K, et al, Clinical Experimental Immunology, 1976, 26, 189.

${ }^{4}$ Cohen, S H, et al, fournal of Allergy and Clinical Immunology, 1978, 62, 217.

5 Donaldson, V H, and Evans, R R, American fournal of Medicine, 1963, 35, 37.

${ }^{6}$ Rosen, F S, et al, Science, 1965, 148, 957.

7 Pillemer, L, Ratnoff, O D, and Lepon, I H, fournal of Experimental Medicine, 1953, 97, 573.

${ }^{8}$ Ratnoff, O D, and Naff, G M, Fournal of Experimental Medicine, 1967, 125, 337.

9 Frank, M M, et al, New England fournal of Medicine, 1972, 286, 808.

10 Sheffer, A L, Austen, K F, and Rosen, F S, New England Fournal of Medicine, 1972, 287, 452.

11 Spaulding, W B, Annals of Internal Medicine, 1960, 53, 739.

12 Sheffer, A L, Fearson, D T, and Austen, K F, Annals of Internal Medicine, 1977, 86, 306.

13 Gelfand, J A, et al, New England fournal of Medicine, 1976, 295, 1444. 